\title{
ELIMINATION OF CHLORAMPHENICOL IN RAINBOW TROUT RECEIVING MEDICATED FEED
}

\author{
Nina BILANDŽIĆ ${ }^{1}$, Ivana VARENINA ${ }^{1}$, Sanin TANKOVIĆ ${ }^{2}$, and \\ Božica SOLOMUN KOLANOVIĆ ${ }^{1}$
}

Department of Veterinary Public Health, Laboratory for Residue Control, Croatian Veterinary Institute, Zagreb, Croatia $^{l}$; Veterinary Office of Bosnia and Herzegovina, Sarajevo, Bosnia and Herzegovina ${ }^{2}$

Received in April 2011

CrossChecked in June 2011

Accepted in July 2011

\begin{abstract}
Chloramphenicol muscle residue levels in rainbow trout were determined after oral administration of $84 \mu \mathrm{g} \mathrm{kg}^{-1} \mathrm{~d}^{-1}$ of chloramphenicol for four days. Samples were taken one day before treatment and for 43 days after the treatment was over. Chloramphenicol was analysed using an in-house enzyme linked immunoassay (ELISA) validated against the criteria of the Commission Decision 2002/657/EC. Validation parameters confirmed that the method was appropriate for the detection of chloramphenicol at levels below the minimum required performance limit (MRPL) of $0.3 \mu \mathrm{g} \mathrm{kg}^{-1}$. The highest chloramphenicol levels were observed on the first day after the treatment had ended $\left(144.3 \mu \mathrm{g} \mathrm{kg}^{-1}\right)$. Elimination was significant over the first seven days; significant differences were detected between days 1 and 3 ( $p<0.001), 3$ and 5 ( $p<0.001$ ), and 5 and $7(\mathrm{p}<0.05)$. Chloramphenicol levels dropped below MRPL to $0.17 \mu \mathrm{g} \mathrm{kg}^{-1}$ on day 9 after the end of treatment. From day 11 to 43, chloramphenicol residues were detectable in a range from $0.091 \mu \mathrm{g} \mathrm{kg}^{-1}$ (highest) to $0.011 \mu \mathrm{g} \mathrm{kg}^{-1}$ (lowest). Our results indicate that trout muscle tissue could be compliant with health requirements for consumption 10 days after withdrawal from chloramphenicol treatment.
\end{abstract}

KEY WORDS: antibiotic, ELISA, freshwater fish, residue

Chloramphenicol is a broad-spectrum antibiotic with well-known bacteriostatic properties effective against both gram-positive and gram-negative bacteria, as well as against other groups of microorganisms. Chloramphenicol binds to the A site of the peptidyltransferase centre, where it disturbs the placement of A site tRNA and thus prevents peptide bond formation (1). Toxicology reports indicate that chloramphenicol can cause bone-marrow depression, a disorder that is reversible after drug withdrawal. On the other hand, chloramphenicol can also cause irreversible aplastic anaemia that can result in leukaemia $(3,4)$. Because of these side effects, in human medicine chloramphenicol is used when less risky drugs are ineffective (2).

Due to risk for human health, the European Union has prohibited the use of chloramphenicol in food- producing animals destined for human consumption (5) and set the minimum required performance limit (MRPL) to $0.3 \mu \mathrm{g} \mathrm{kg}^{-1}$ as the minimum content of chloramphenicol in several matrices, including aquaculture products, to be detected and confirmed by analytical methods (6). However, chloramphenicol may still be in use in some developing countries owing to its low cost $(7,8)$. Drug residues have been detected in all kinds of animal products imported to the EU, especially in honey, shrimp, and other aquatic animals such as fish, mostly of Asian origin. This raises great concern about the impact on consumer health.

Viral and bacterial diseases are common in aquaculture, especially with high stocking densities. In the past, chloramphenicol was used as a chemotherapeutic agent to control diseases or as a 
prophylaxis or disinfectant to prevent disease, either through direct application into the aquatic environment or through medicated feeds in a mass fraction of (4 to 8$) \mathrm{g}$ per $100 \mathrm{~kg}(9,10)$. Chloramphenicol absorbs well in the gastrointestinal tract and its elimination half-time varies widely between species. Its lipid solubility enables the molecule to persist in most tissues, body fluids, and the central nervous system, and it readily diffuses to milk and eggs (11). Chloramphenicol residues in aquaculture products may present a risk to public health, while residues in water and sediment endanger the aquatic environment (12).

Rainbow trout is the most cultivated freshwater species in aquaculture worldwide. Fish production is increasing annually in countries such as Italy, France, Germany, Denmark and Spain. Large production of fish has also been registered in the USA, Iran, Germany and the United Kingdom (13). However, only a few studies have investigated chloramphenicol elimination in fish species before they reach consumers $(14,15)$.

The aim of our study was to determine the elimination time of chloramphenicol in rainbow trout after oral treatment with medicated feed over a four-day period using a validated enzyme immunoassay method.

\section{MATERIALS AND METHODS}

\section{Fish treatment and sampling}

Rainbow trout (Oncorhynchus mykiss) were kept in $4.7 \mathrm{~m}^{3}$ fibreglass tanks supplied with a constant flow of $720 \mathrm{~L} \mathrm{~h}^{-1}$ of water with oxygen content of $(92.8 \pm 3.1) \%$ at a temperature of $(9.7 \pm 0.1)^{\circ} \mathrm{C}, \mathrm{pH}$ (7.5 \pm 0.1 ). The average mass of a trout was (200 to 250) $\mathrm{g}, \mathrm{n}=200$.

For a daily chloramphenicol therapeutic dose of $84 \mathrm{mg} \mathrm{kg}^{-1} \mathrm{~d}^{-1}$, feed (500 $\mathrm{g}$ pellets) was added $28 \mathrm{~mL}$ of chloramphenicol solution $\left(150 \mathrm{mg} \mathrm{mL}^{-1}\right.$; Jiangxi Dongxu Chemical Technology Ltd., China) and mixed well to achieve homogeneity of the drug throughout the matrix. Twice a day the fish received $0.5 \mathrm{~kg}$ of medicated pellets per $100 \mathrm{~kg}$ of fish.

Samples were taken at random one day before treatment (baseline), and then on day 1 after treatment ended, and on every second (odd) day until day 43 (Table 1). On each sampling day, three fish were taken from a tank, their skin and internal organs removed, and muscle tissues and random subcutaneous fat partly homogenised, packed in plastic bags and stored at $-18{ }^{\circ} \mathrm{C}$ until analysis.

\section{Reagents and standards}

Chloramphenicol kit (type E.G.1) was provided by the Laboratory of Hormonology (Marloie, Belgium) and consisted of a microtitre plate ( 96 wells), standard solutions of chloramphenicol $[(0,0.05,0.1,0.2,0.5$, 1 and 2) $\mathrm{ng} \mathrm{mL}^{-1}$, concentration conjugate (peroxidase conjugated chloramphenicol), lyophilised antichloramphenicol antibody, substrate/chromogen solution (peroxide/tetramethylbenzidine) dilution buffer ( $\mathrm{pH}$ 7.4), stop solution (6 $\left.\mathrm{N} \mathrm{H}_{2} \mathrm{SO}_{4}\right)$, and a rinsing buffer.

Chloramphenicol standard was from SigmaAldrich (St. Louis, MO, USA). All reagents were of analytical, HPLC, or LC-MS grade. Methanol,

Table 1 Mass fractions of chloramphenicol (mean $\pm S D, n=3$ ) in the muscle of rainbow trout one day before (baseline) and for 43 days after the end of treatment with doses of $84 \mathrm{mg} \mathrm{kg}^{-1} \mathrm{~d}^{-1}$ in medicated feed

\begin{tabular}{lcc}
\hline \multirow{2}{*}{ Day } & \multicolumn{2}{c}{ Mass fraction $/ \mathbf{~ g ~ k g ~}^{-1}$} \\
\cline { 2 - 3 } & \multicolumn{2}{c}{ Mean } \\
\hline Before treatment & 0.009 & 0.002 \\
\hline 0 & & \\
\hline Elimination time & 144.3 & 21.7 \\
\hline 1 & 28.1 & 6.1 \\
\hline 3 & 3.0 & 1.5 \\
\hline 5 & 0.34 & 0.2 \\
\hline 7 & 0.17 & 0.051 \\
\hline 9 & 0.091 & 0.014 \\
\hline 11 & 0.057 & 0.017 \\
\hline 13 & 0.045 & 0.012 \\
\hline 15 & 0.069 & 0.016 \\
\hline 17 & 0.038 & 0.009 \\
\hline 19 & 0.041 & 0.005 \\
\hline 21 & 0.029 & 0.006 \\
\hline 23 & 0.03 & 0.005 \\
\hline 25 & 0.019 & 0.002 \\
\hline 27 & 0.018 & 0.006 \\
\hline 31 & 0.017 & 0.01 \\
\hline 33 & 0.015 & 0.001 \\
\hline 35 & 0.014 & 0.002 \\
\hline 37 & 0.013 & 0.004 \\
\hline 39 & 0.014 & 0.002 \\
\hline 41 & 0.013 & 0.001 \\
\hline 43 & 0.011 & 0.005 \\
\hline & & \\
\hline
\end{tabular}


dichloromethane, diethyl ether, and isooctane were supplied by Carlo Erba (Milan, Italy).

Nitrogen 5.0 and nitrogen 5.5 were purchased from SOL spa (Monza, Italy). Ultra-high purity water was processed through a purification system NIRO VV UV UF 20 (Nirosta d.o.o. Water Technologies, Osijek, Croatia).

Standard stock solutions were prepared on a weekly basis by dissolving the analyte in methanol. Intermediate working solutions were prepared before each analysis by diluting stock solutions in methanol. Working solutions were used for spiking blank fish muscle samples at different levels. Following fortification, samples were allowed to equilibrate for 15 min before extraction.

\section{Sample preparation}

A total of $3 \mathrm{~g}$ of homogenised fish sample was weighed and mixed with $3 \mathrm{~mL}$ of distilled water. Chloramphenicol was extracted from the matrix by adding $6 \mathrm{~mL}$ of ethyl acetate and mixing with a dispersing system for 10 minutes. After centrifugation (1006 rpm, $10 \mathrm{~min}$ ), $5 \mathrm{~mL}$ supernatant was taken and evaporated with nitrogen until dry at $50{ }^{\circ} \mathrm{C}$. Residues were dissolved with $1 \mathrm{~mL}$ isooctane/dichloromethane mixture (2:3) and mixed intensively with $0.5 \mathrm{~mL}$ of dissolving buffer (from kit accessories) for $1 \mathrm{~min}$ and then centrifuged at $1006 \mathrm{rpm}$ for $10 \mathrm{~min}$. If an emulsion appeared in the upper layer, residues were heated for $2 \mathrm{~min}$ in a water bath at $80{ }^{\circ} \mathrm{C}$ and centrifuged again. For the EIA test, $50 \mu \mathrm{L}$ of the upper layer was used. Immunoassays were performed according to the manufacturer's instructions. The absorbance for all assays was measured at $450 \mathrm{~nm}$.

\section{Instrumental}

The following instruments were used in sample preparation: IKA ${ }^{\circledR}$ Ultra-Turrax ${ }^{\circledR}$ model T25 and IKA ${ }^{\circledR}$ Vortex model Genius 3 (IKA ${ }^{\circledR}$-WERKE GMBH \& CO.KG, Germany), centrifuge Rotanta 460R (Hettich zentrifugen, Tuttlingen, Germany), water bath GFL model 1083 (Gesellscaft fur Labortechnik GmbH, Burgwedel, Germany), nitrogen evaporation system N-EVAP model 111 (Orgamonation Associates Inc., Berlin, USA), and a $\mathrm{pH}$ meter inoLAB WTW (Wilheilm, Germany). The optical density at $450 \mathrm{~nm}$ was measured by the microplate reader Tecan model Sunrise Absorbance Reader (Tecan Austria GmbH, Salzburg, Austria).

\section{Validation}

Method performance characteristics were determined according to the criteria laid down by the Commission Decision 2002/657/EC for qualitative screening methods (16). The limit of detection (LOD) was determined by adding the analyte in quantities three and 10 times of 20 mean blank samples. Response linearity was calculated from a six-point calibration curve $\left[(0.625 ; 1.25 ; 2.5 ; 5 ; 10) \mu \mathrm{g} \mathrm{kg}^{-1}\right]$.

Method trueness and precision were determined by fortifying blank muscle samples with chloramphenicol at $(0.15 ; 0.3 ; 0.45) \mu \mathrm{g} \mathrm{kg}^{-1}$ in six replicates for each level and analysing them three times. The decision limit $\mathrm{CC} \alpha$ was evaluated by analysing 20 blank milk samples fortified with the analyte at the lowest calibration level $\left(0.15 \mu \mathrm{g} \mathrm{kg}^{-1}\right)$ plus 2.33-fold within-laboratory standard deviation calculated at this level $(n=18)$. The value of the decision limit plus 1.64 times the corresponding standard deviation equals detection capability $\mathrm{CC} \beta$ $(\beta=5 \%)$.

\section{Statistical analysis}

Analysis of variance was performed using the Statistica ${ }^{\circledR} 6.1$ software package (StatSoft ${ }^{\circledR}$ Inc., Tulsa, USA). Results were expressed as mean \pm SD. Differences in chloramphenicol concentrations between days were analysed using Student's $t$-test for independent pairs. Probability values of $\leq 0.05$ were considered statistically significant.

Table 2 Recovery and accuracy results of ELISA methods used for chloramphenicol determination in trout

\begin{tabular}{|c|c|c|c|c|}
\hline \multicolumn{2}{|c|}{ Mass fraction / $\mu \mathrm{g} \mathrm{kg}^{-1}$} & \multirow{2}{*}{ Recovery / \% } & \multirow{2}{*}{ Standard deviation } & \multirow{2}{*}{$\mathrm{CV} / \%$} \\
\hline Spiked & Measured & & & \\
\hline 0.15 & 0.16 & 108.4 & 0.021 & 10.6 \\
\hline 0.3 & 0.28 & 92.4 & 0.024 & 9.8 \\
\hline \multirow[t]{2}{*}{0.45} & 0.35 & 78.8 & 0.035 & 9.5 \\
\hline & Mean value & 93.2 & 0.027 & 9.97 \\
\hline
\end{tabular}




\section{RESULTS AND DISCUSSION}

Elimination of chloramphenicol was estimated over 43 days after the end of treatment with chloramphenicol in the dose of $84 \mathrm{mg} \mathrm{kg}^{-1}$ day $^{-1}$. Analysis was performed by using enzyme linked immunoassay (ELISA) method, in-house validated to the criteria of Commission Decision 2002/657/EC. In the validation study, the detection capability was $\mathrm{CC} \beta=0.23 \mu \mathrm{g} \mathrm{kg}^{-1}$ and the limit of detection (LOD) $0.0008 \mu \mathrm{g} \mathrm{kg}^{-1}$. Trueness was expressed in terms of recovery (Rec / \%) with a mean value of $93.2 \%$ at three mass fraction levels (Table 2). The coefficient of variation $(\mathrm{CV} / \%)$ for the lowest spiked concentration was $10.6 \%(<20 \%)$. Validation parameters indicated that the method was appropriate for detection of chloramphenicol at levels below the MRPL of $0.3 \mu \mathrm{g} \mathrm{kg}^{-1}$.

Table 1 shows mean mass fractions of chloramphenicol in the muscle of rainbow trout, on baseline and 43 days after the treatment ended. The highest chloramphenicol levels were detected on day 1 after the end of treatment $\left(144.3 \mu \mathrm{g} \mathrm{kg}^{-1}\right)$. Over the next 33 days levels kept dropping from $28.1 \mu \mathrm{g} \mathrm{kg}^{-1}$ on day 3 to $0.015 \mu \mathrm{g} \mathrm{kg}^{-1}$ on day 33. Significant elimination took place over the first 7 days after the end of treatment, and significant differences were detected between days 1 and $3(p<0.001), 3$ and 5 $(\mathrm{p}<0.001)$, and 5 and $7(\mathrm{p}<0.05)$. Between days 33 and 43 after the end of treatment, chloramphenicol levels decreased more slowly from $0.015 \mu \mathrm{g} \mathrm{kg}^{-1}$ to $0.011 \mu \mathrm{g} \mathrm{kg}^{-1}$.

In a recent study conducted on rainbow trout receiving chloramphenicol in the dose of $73.9 \mathrm{mg}$ $\mathrm{kg}^{-1} \mathrm{~d}^{-1}$ over 10 days (15), mean chloramphenicol level was $35.781 \mu \mathrm{g} \mathrm{kg}^{-1}$ on day 1 after the end of treatment. This level is more than 250 times higher than in our study and may be due to a 2.5 times longer treatment period. Moreover, in that study trout were kept in tanks with a constant flow of $8 \mathrm{~L} \mathrm{~h}^{-1}$, as opposed to a 90 times higher water flow in our study $\left(720 \mathrm{~L} \mathrm{~h}^{-1}\right)$. Accordingly, chloramphenicol levels in our study dropped below MRPL of $0.3 \mu \mathrm{g} \mathrm{kg}^{-1}$ on day 9 $\left(0.171 \mu \mathrm{g} \mathrm{kg}^{-1}\right)$ after the end of treatment. In the elimination period from day 11 to 43 , chloramphenicol residues were detectable in the range from a maximum of $0.091 \mu \mathrm{g} \mathrm{kg}^{-1}$ to a minimum of $0.011 \mu \mathrm{g} \mathrm{kg}^{-1}$. In contrast, in the trout treated over 10 days (15), chloramphenicol levels were still at $0.3 \mu \mathrm{g} \mathrm{kg}^{-1} 31$ days after the end of treatment.
In a study on shrimp (Penaeus chinensis) receiving a diet containing $2000 \mathrm{mg} \mathrm{kg}^{-1}$ of chloramphenicol a day over three days, the elimination of chloramphenicol to below MRPL took three days (14). It may be concluded that withdrawal periods vary widely among species (17).

High chloramphenicol mass fractions ranging from $0.1 \mu \mathrm{g} \mathrm{kg}^{-1}$ to $34 \mu \mathrm{g} \mathrm{kg}^{-1}$ were measured in samples of aquaculture products in Ireland in 2002 (2). High chloramphenicol average of $0.25 \mu \mathrm{g} \mathrm{kg}^{-1}$, (range: $0.06 \mu \mathrm{g} \mathrm{kg}^{-1}$ to $0.69 \mu \mathrm{g} \mathrm{kg}^{-1}$, with two outlying values of $3.0 \mu \mathrm{g} \mathrm{kg}^{-1}$ and $3.7 \mu \mathrm{g} \mathrm{kg}^{-1}$ ) was also confirmed in shrimp samples (2). During the past decade, chloramphenicol residues ranging from $0.3 \mu \mathrm{g} \mathrm{kg}^{-1}$ to $3.5 \mu \mathrm{g} \mathrm{kg}^{-1}$ were reported in fish and fish products imported to the EU, mainly from China and Vietnam (18). The highest cloramphenicol value of $3.5 \mu \mathrm{g} \mathrm{kg}-$ ${ }^{1}$ was measured in Germany in eel imported from China. These data confirm the intentional use of the drug in products imported from developing countries and call for control of its abuse in aquaculture products.

\section{CONCLUSIONS}

Our results show that trout tissue could be compliant for consumption with no potential risk to health after a 10-day withdrawal period.

The method validated and used is very sensitive and able to detect chloramphenicol after the first ten days after treatment. The method is able to protect consumers since it is capable of detecting small concentrations of chloramphenicol. Also, if treatment with chloramphenicol is not permitted in Europe, the use of this method to control fish imported from Asian Countries should represent a guarantee that fish had undergone a 10-day withdrawal period.

\section{Acknowledgements}

The authors wish to acknowledge Mirjana Hren and Tamara Nekić for their assistance in sample preparation.

\section{REFERENCES}

1. Cannon M, Harford S, Davies J. A comparative study on the inhibitory actions of chloramphenicol, thiamphenicol and some fluorinated derivatives. J Antimicrob Chemother 1990;26:307-17. 
2. World Health Organization (WHO). Toxicological evaluation of certain veterinary drug residues in food. WHO Food Additives Series 53. Geneva: WHO; 2004.

3. Anadón A, Bringas P, Martinez-Larrañaga MR, Diaz MJ. Bioavailability, pharmacokinetics and residues of chloramphenicol in the chicken. J Vet Pharmacol Ther 1994; 17:52-8.

4. Holt DE, Bajoria R. The role of nitro-reduction and nitric oxide in the toxicity of chloramphenicol. Hum Exp Toxicol 1999; 18:111-8.

5. European Council Regulation $37 / 2010 / E U$ of 22 December 2009 on pharmacologically active substances and their classification regarding maximum residue limits in foodstuffs of animal origin. Off J Eur Commun 2010;L15:1-72.

6. European Commission Decision 2003/181/EC of 13 March 2003 on amending Decision 2002/657/EC as regard the setting of minimum required performance limits (MRPLs) for certain residues in food of animal origin. Off $\mathrm{J}$ Eur Commun 2003;L71:17.

7. Ferguson J, Baxter A, Young P, Kennedy G, Elliott C, Weigel S, Gatermann R, Ashwin H, Stead S, Sharman M. Detection of chloramphenicol and chloramphenicol glucuronide residues in poultry muscle, honey, prawn and milk using a surface plasmon resonance biosensor and Qflex $^{\circledR}$ kit chloramphenicol. Anal Chim Acta 2005;529:109-13.

8. Tajik H, Malekinejad H, Razavi-Rouhani SM, Pajouhi MR, Mahmoudi R, Haghnazari A. Chloramphenicol residues in chicken liver, kidney and muscle: A comparison among the antibacterial residues monitoring methods of Four Plate Test, ELISA and HPLC. Food Chem Toxicol 2010;48:2464-8.

9. Cravedi JP, Choubert G, Delous G. Digestibility of chloramphenicol, oxolinic acid and oxytetracycline in rainbow trout and influence of these antibiotics on lipid digestibility. Aquaculture 1987;60:133-41.

10. Ervik A, Thorsen B, Eriksen V, Lunestad BT, Samuelsen OB. Impact of administering antibacterial agents on wild fish and blue mussels Mytilus edulis in the vicinity of fish farms. Dis Aquat Organ 1994;18:45-51.

11. Dowling PM. Chloramphenicol, thiamphenicol, and florfenicol. In: Giguère S, Prescott JF, Baggot JD, Walker $\mathrm{RD}$, Dowling PM, editors. Antimicrobial therapy in veterinary medicine. $4^{\text {th }}$ ed. London: Blackwell Publishing; 2006.

12. Lu XW, Dang Z, Yang C. Preliminary investigation of chloramphenicol in fish, water and sediment from freshwater aquaculture pond. Int J Environ Sci Technol 2009;6:597604.

13. Food and Agriculture Organisation in the United Nations, Fisheries and Aquaculture Department. Cultured Aquatic Species Information Programme Oncorhynchus mykiss (Walbaum, 1792) [displayed 15 July 2011]. Available at http://www.fao.org/fishery/culturedspecies/ Oncorhynchus_mykiss/en.

14. Wang W, Lin H, Xue C, Khalid J. Elimination of chloramphenicol, sulphamethoxazole and oxytetracycline in shrimp, Penaeus chinensis following medicated-feed treatment. Environ Int 2004;30:367-73.

15. Biancotto G, Contiero L, Benetti C, Calligaris, M, Tibaldi, E, Cerni, L, Francese M. Depletion of chloramphenicol in trout after a hypothetic therapeutic treatment. Anal Chim Acta 2009;637:173-7.

16. The Commission of the European Communities. Commission decision 14 of august 2002, implementing council directive 96/23/EC concerning the performance of analytical methods and the interpretation of results 2002/657/EC. Off J Eur Commun 2002;L221:8-36.

17. Pengov A, Cerkvenik Flajs V, Zadnik T, Marinšek J, Pogačnik M. Distribution of chloramphenicol residues in lactating cows following an external application. Anal Chim Acta 2005;529:347-51.

18. Rapid alert system for food and feed (RASFF) [displayed 15 July 2011]. Available at http://ec.europa.eu/food/food/ rapidalert/index_en.htm. 


\section{Sažetak}

\section{ELIMINACIJA KLORAMFENIKOLA U KALIFORNIJSKOJ PASTRVI}

Određivani su ostaci kloramfenikola u mišićnom tkivu kalifornijske pastrve nakon oralne primjene u dozi od $84 \mu \mathrm{g} \mathrm{kg}^{-1} \mathrm{~d}^{-1}$ tijekom 4 dana. Uzorkovanje je provedeno dan prije tretmana te tijekom 43 dana nakon tretmana. Maseni udjeli kloramfenikola određivani su primjenom in-house imunoenzimske metode (ELISA) validirane prema kriterijima Odluke Komisije 2002/657/EC. Dobiveni validacijski parametri pokazuju da je metoda prikladna za određivanje kloramfenikola na nivou manjem od vrijednosti granice najmanje zahtijevane učinkovitosti izvedbe metode (MRPL) od $0,3 \mu \mathrm{g} \mathrm{kg}^{-1}$. Najviši maseni udjeli kloramfenikola utvrđeni su prvog dana nakon završetka tretmana $\left(144,3 \mu \mathrm{g} \mathrm{kg}^{-1}\right)$. Statistički značajna eliminacija utvrđena je tijekom sedam dana te je značajno smanjenje određeno između prvog i trećeg $(p<0,001)$, trećeg i petog $(p<0,001)$ te petog i sedmog dana nakon tretmana $(p<0,05)$. Razina kloramfenikola ispod MRPL vrijednosti utvrđena je devetog dana $\left(0,17 \mu \mathrm{g} \mathrm{kg}^{-1}\right)$ nakon tretmana. U vremenu od 11. do 43. dana nakon tretmana određeni su ostaci kloramfenikola od maksimalno $0,091 \mu \mathrm{g} \mathrm{kg}^{-1}$ do minimalno $0,011 \mu \mathrm{g} \mathrm{kg}^{-1}$. Prikazani rezultati pokazuju da se 10 dana nakon završetka tretmana tkivo pastrve može smatrati prikladnim za konzumaciju bez potencijalne štete za zdravlje.

KLJUČNE RIJEČI: antibiotik, deplecija, ELISA, ostaci, riječna riba

\section{CORRESPONDING AUTHOR:}

Nina Bilandžić

Croatian Veterinary Institute

Department of Veterinary Public Health, Laboratory

for Residue Control

Savska cesta 143, 10000 Zagreb, Croatia

E-mail: bilandzic@veinst.hr 